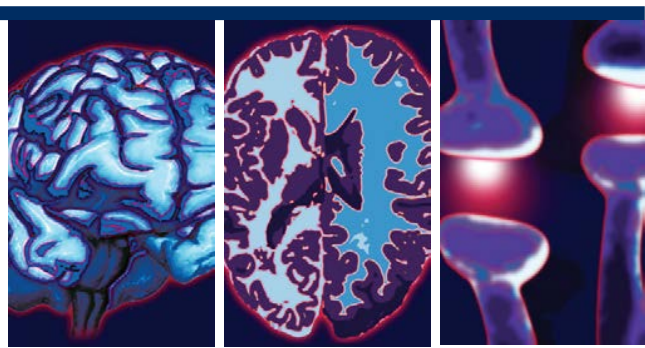

\title{
Landau-Kleffner Syndrome: An Unusual Case With Progressive Ataxia Prior To Language Regression And Autistic-Like Behaviors
}

Wen-Xiong Chen ${ }^{\dagger}$, Si-Da Yang, Yuan-Yuan Gao, Shu-Yao Ning, Bin-Wei Peng, Ya-Ni Zhang, Yin-Yan Zhong, Ke-Lu Zheng, Shao-Ping Ou

\begin{abstract}
Objective

To report a case with Landau-Kleffner syndrome (LKS) presenting with unusual clinical features.

\section{Methods}

The clinical features of the case including clinical manifestations, serial electroencephalography (EEG) outcomes, neuroimaging findings, neuropsychological outcomes, interventional approaches and long-term follow-up outcomes, were analyzed.
\end{abstract}

\section{Results}

This previously normal girl $(3 \mathrm{y} 10 \mathrm{~m})$, presented with progressive ataxia as an onset symptom, ensued with cognitive impairments and language regressions (characterized by verbal auditory agnosia and expressive aphasia), and autistic-like behaviors. She had no evidence of clinical seizures, with normal brain and spine MRI scans, intact auditory exams and normal brain auditory evoked potential, although the sleep- activated inter-ictal epileptiform discharges of EEG were revealed. The patient showed gradual resolution of symptoms with long-term high-dose steroids plus intravenous immunoglobulin (IVIG) regimens, in consistence with the gradual improvement of the outcomes of serial EEGs. She recovered and returned to normal kindergarten $1 \mathrm{y} 1 \mathrm{~m}$ after the onset of the disease, consistent with the normal EEG results. Her full-scale intelligence quotient (IQ) was 71 score, with verbal IQ 66 and performance IQ 81 respectively, tested at the time of $1 \mathrm{y} 3 \mathrm{~m}$ after the onset. The long-term prognosis of the case was good as she had good academic performance and was a monitor of the class at the time of her long-term follow-up of 5y8m after the onset.

\section{Conclusion}

LKS is heterogeneity entity, especially for those with the atypical onset such as ataxia, as well as absence of clinical seizures. The combination of long-term high-dose steroid plus IVIG regimens may be especially effective in LKS.

\section{Key words}

Landau-Kleffner syndrome (LKS), Ataxia, Language regressions, Autistic-like behaviors, Cognitive impairments, Steroid

Department of Neurology, Brain Center, Guangzhou Women and Children's Medical Center, Guangzhou Medical University, Guangzhou City, Guangdong Province, China

${ }^{\dagger}$ Author for correspondence: Dr. Wen-Xiong Chen, Department of Neurology, Brain Center, Guangzhou Women and Children's Medical Center Guangzhou Medical University, 9\# Jin Sui Road, 510623, Guangzhou City, Guangdong Province P.R. of China, Tel: 86-02038076127; email: chenwenxiong@gwcmc.org 


\section{Introduction}

Landau-Kleffner syndrome (LKS) or acquired epileptic aphasia, first described by Landau and kleffler in 1957 [1], is a rare childhood neurological disorder, being characterized by an acquired aphasia that emerges in relation to epileptiform electroencephalographic (EEG) abnormalities [1,2].

The most prominent defining feature of LandauKleffner syndrome is an acquired aphasia [2], whereas epileptic seizures are not a prerequisite for LKS. The typical type of aphasia is a verbal auditory agnosia, failure to provide a semantic significance to the different sounds. The loss of receptive language is followed or simultaneously occurred by expressive aphasia, a marked reduction in spontaneous speech. Other clinical manifestations include cognitive impairments and behavioral problems. These impairments may be global or focal, based on the location of the epileptic discharges, and progressive, presumably related to increasing epileptiform activity.

LKS is a heterogeneous entity, with rather significant variations in terms of age of onset, the aphasia's characteristics, EEG abnormalities, and comorbid cognitive and behavioral impairments [3], leading to the challenges of diagnosis. We reported an unusual LKS girl presenting with atypical onset prior to typical manifestations, and her long-term follow-up outcomes.

\section{Case report}

A previous healthy girl with LKS was reported, who was the $2^{\text {nd }}$ child of the three children' family, a full-term baby (birth weight: $3.35 \mathrm{~kg}$ ) via virginal sections following a normal 40 weeks pregnancy with unremarkable events and did not require support services after birth. The child's early developmental milestones achieved all the developmental domains including expressive and receptive language at the appropriate time with the babbling at 8 month, first word at 11 month, combining words available at the age of 2 years, when she generated sentences of 3 and 4 words with a good verbal comprehension. There was no other pertinent medical history before age 3 years and 10 months $(3 y 10 \mathrm{~m})$. She had no known family history of epilepsy and other neurological disorders. Her older sister and younger brother did not have the same disorders as the girl had.

The age of onset was $3 y 10 \mathrm{~m}$, presenting with progressive ataxia prior to cognitive impairments and language regressions, and autistic-like behaviors. The clinical features of the case including clinical manifestations, neurological examinations, clinical investigations and treatments were summarized in the Table 1. The research protocol was approved by the Institutional Review Board of the Guangzhou Women and Children's Medical Center. Written informed consent was obtained from the parents.

\section{Discussion}

Landau-Kleffner syndrome (LKS) is a rare childhood epileptic encephalopathy, along with a deterioration of cognitive, sensory, and/or motor functions results from epileptic activity [4]. One Japanese study has reported that the incidence of children with LKS aged 5 14 years was around 1 in a million in Japan [5].

\section{- LKS and onset}

Age of onset: LKS commonly occurs between the ages of 3 and 7 years based on the ICD-10 guidelines, although onset as early as 18 22 months and as late as 13 14 years has also been stated. The mean age of onset of aphasia was 4.8 years with standard deviation 2.2 years was revealed, according to the analysis of 268 out of 337 LKS cases from the published English literatures [3]. Of which, the most cases (around $90 \%$ ) presenting their onset was between the ages of 2 and 7 years old and approximately one third of these cases regressed before their 4 years old [3]. The age of onset of the case in our study was 3 years and 10 months, like most reported other cases before their fourth birthday, although she had an unusual neurological symptom's onset.

Symptom of onset: The onset of LKS may be insidious or sudden. One study reported that the language deterioration was the onset symptom found in the most cases [6], whereas other studies have stated that the epileptic seizures being the initial symptoms more often than the language disturbances [7]. In some rare cases, the parents claimed that they in fact gradually lost contact with their pediatric subjects, which might be attributed to the psychogenic regression [8].

In the current study, a previously normal girl with an onset of progressive ataxia without obvious precipitating factors at around 2-months prior to cognitive impairments and language regressions, and behavioral disturbances was reported. One Japanese study [9] had ever reported one case whose symptom of onset somewhat similar to our case, having ataxia before language regressions, 
Landau-Kleffner Syndrome: An Unusual Case With Progressive Ataxia Prior To Language Case Report Regression And Autistic-Like Behaviors

\begin{tabular}{|c|c|c|c|c|}
\hline Phases/Date of visit & Clinical manifestations & Neurological & $\begin{array}{l}\text { Main clinical } \\
\text { investigations }\end{array}$ & Treatments \\
\hline /Visiting methods & & examinations & & \\
\hline \multirow[t]{2}{*}{ A/26-11-2012 12-12-20 } & $\begin{array}{l}\text { 1.Progressive ataxia without precipitating } \\
\text { factors at the age of onset } 3 y 10 \mathrm{~m} ; 2 \text {. The } \\
\text { unusual posture when up and down stairs } \\
\text { as the symptom of onset noted by parent; } \\
\text { 3. Followed by the abnormal gait with } \\
\text { wide-base, walking unsteadily and easily } \\
\text { falling }\end{array}$ & $\begin{array}{l}\text { NE at admission: Normal } \\
\text { except cerebellar signs with } \\
\text { wise-base gait and truncal } \\
\text { ataxia. }\end{array}$ & 1. CSF: Normal; & $\begin{array}{l}\text { 1. Progressive } \\
\text { cerebellar ataxia was } \\
\text { diagnosed. }\end{array}$ \\
\hline & down. & & & $\begin{array}{l}\text { 2. Treated with 4 day } \\
(0.5\end{array}$ \\
\hline \multirow[t]{4}{*}{$\begin{array}{l}\text { 12/Hospitalization at local } \\
\text { tertiary medical college } \\
\text { affiliated hospital (after } 2 \\
\text { days of onset). }\end{array}$} & & & $\begin{array}{l}\text { 2. Bilateral calcaneus, } \\
\text { lumbar and pelvic x } \\
\text { ray: Normal; }\end{array}$ & $\begin{array}{l}\mathrm{g} / \mathrm{kg} / \mathrm{d}) \text { IVIG }+3 \sim \text { day } \\
\text { high dose }(20 \mathrm{mg} / \\
\mathrm{kg} / \mathrm{d}) \text { MPN, followed } \\
\text { by } 4 \sim \text { day IV Dex }(0.25 \\
\mathrm{mg} / \mathrm{kg} / \mathrm{d}) .\end{array}$ \\
\hline & & & $\begin{array}{l}\text { 3.1 hour VEEG: } \\
\text { Sleep-activity bilateral } \\
\text { central-temporal IEDs } \\
\text { without clinical events; }\end{array}$ & $\begin{array}{l}\text { 3. A slight } \\
\text { improvement on } \\
\text { sitting posture after } \\
\text { treatment. }\end{array}$ \\
\hline & & & $\begin{array}{l}\text { 4. Brain CT/MRI and } \\
\text { Spine MRI }\end{array}$ & \\
\hline & & & (Scan): Normal. & \\
\hline \multirow[t]{2}{*}{ B/12-12-2012 21-12-20 } & During hospitalization: & $\begin{array}{l}\text { NE at admission: Normal } \\
\text { except walking unsteadily } \\
\text { with wide-base gait. }\end{array}$ & $\begin{array}{l}\text { 1. Repeated CSF: } \\
\text { Normal; }\end{array}$ & $\begin{array}{l}\text { Oral prednisone } \\
(1 \mathrm{mg} / \mathrm{kg} / \mathrm{d}) \text { was } \\
\text { continued. }\end{array}$ \\
\hline & $\begin{array}{l}\text { 1. Markedly improved in the walking } \\
\text { posture after treatment with just left } \\
\text { slightly unstable walking posture at } \\
\text { discharge; } 2 \text {. The status of restlessness or } \\
\text { agitation noted sometimes. }\end{array}$ & & & \\
\hline \multirow[t]{2}{*}{$\begin{array}{l}\text { 12/Hospitalization at } \\
\text { GZWCMC. }\end{array}$} & & & $\begin{array}{l}\text { 2. 1 hour VEEG: } \\
\text { Normal; }\end{array}$ & \\
\hline & & & $\begin{array}{l}\text { 3. Repeated brain MRI } \\
\text { (Scan + Contrast): } \\
\text { Normal }\end{array}$ & \\
\hline \multirow[t]{2}{*}{$\begin{array}{l}\text { C/08-01-2013/Outpatien t } \\
\text { at GZWCMC. }\end{array}$} & 1. Ataxia was complete recovery; & $\begin{array}{l}\text { NE at outpatient: Walking } \\
\text { posture normal, but less } \\
\text { communicated }\end{array}$ & $\mathrm{Nil}$ & $\begin{array}{l}\text { Oral prednisone was } \\
\text { tapered off after a total }\end{array}$ \\
\hline & $\begin{array}{l}\text { 2. Somewhat less desires to communicate } \\
\text { with others and less lively during daily life } \\
\text { noted by parent. }\end{array}$ & with doctor. & & $\begin{array}{l}1.75 \text { months course of } \\
\text { steroid. }\end{array}$ \\
\hline \multirow[t]{2}{*}{ D/08-01-2013 04-03-20 } & $\begin{array}{l}\text { 1. Verbal auditory agnosia: Did } \\
\text { not understand what parents' or } \\
\text { grandmother's said, e.g. asking her to call } \\
\text { grandmother, she went to get a broom } \\
\text { instead. 2. Expressive aphasia: Almost } \\
\text { simultaneously, spontaneous speech } \\
\text { gradually reduced with paraphasias and } \\
\text { impairments in fluency and articulation, } \\
\text { and even mutism sometimes. 3. Autistic- } \\
\text { like behaviors: Including hyperactive, } \\
\text { irritable, impulsivity, just did or played } \\
\text { something she liked, stayed alone, } \\
\text { no response to name call, although } \\
\text { sometimes could take telephone up } \\
\text { when ringing. } 4 \text {. Others: Intelligence, } \\
\text { memory and learning }\end{array}$ & Nil & $\mathrm{Nil}$ & Nil \\
\hline & abilities backward noted by parent. & & & \\
\hline & & & & \\
\hline
\end{tabular}




\section{Case Report Dr. Wen-Xiong Chen}

\begin{tabular}{|c|c|c|c|c|}
\hline E/04-03-2013 21-03-20 & During hospitalization: & $\begin{array}{l}\text { NE at admission: Normal } \\
\text { except less spontaneous }\end{array}$ & $\begin{array}{l}\text { 1. Repeated brain MRI } \\
\text { (Scan + Contrast) } \\
\text { and MRA: Normal; } 2 \text {. } \\
\text { Auditory exam and } \\
\text { BAEP: }\end{array}$ & $\begin{array}{l}\text { 1. The suspected LKS } \\
\text { was made; }\end{array}$ \\
\hline & $\begin{array}{l}\text { 1. Some abnormal behaviors: occupied } \\
\text { the bench, stereotyped behaviors (e.g. } \\
\text { repeatedly touched her }\end{array}$ & speech with & Normal; & $\begin{array}{l}\text { 2. Repeated 5 day } \\
\text { course }\end{array}$ \\
\hline \multirow[t]{4}{*}{$\begin{array}{l}\text { 13/Hospitalization at } \\
\text { GZWCMC. }\end{array}$} & & & & $(0.4 \mathrm{~g} / \mathrm{kg} / \mathrm{d}) \mathrm{IVIG}$ \\
\hline & & & & 3.Parent hesitated to \\
\hline & $\begin{array}{l}\text { toes), and weird behaviors (e.g. went } \\
\text { to other wards to get the high-heeled } \\
\text { shoes). } 2 \text {. A little bit improved in } \\
\text { communication, and a slightly more } \\
\text { vocalizations and more frequencies of }\end{array}$ & $\begin{array}{l}\text { Dysarthria and non- } \\
\text { meaningful vocalizations; } \\
\text { reluctant to communicate }\end{array}$ & $\begin{array}{l}\text { 3. Two 1 hour VEEGs } \\
\text { tested at the interval of } \\
7 \text { days, with the nearly } \\
\text { similar outcomes: } \\
\text { Sleep-activity bilateral } \\
\text { frontal-temporal IEDs } \\
\text { without }\end{array}$ & $\begin{array}{l}\text { accept the long-term } \\
\text { high-dose steroid } \\
\text { regimen or AEDs for } \\
\text { her daughter, instead } \\
\text { choosing to discharge } \\
\text { for further observation } \\
\text { the changes of her } \\
\text { daughter at home. }\end{array}$ \\
\hline & laughs after IVIG treatment. & with others. & clinical events. & \\
\hline F/21-03-2103 10-04-20 & $\begin{array}{l}\text { 1. Some abnormal } \\
\text { behaviors:Hyperactivity, irritability, easily } \\
\text { temper tantrum, compulsive behaviors } \\
\text { (insisting on grandmother should } \\
\text { company with her every night when } \\
\text { sleep),stereotype behaviors }\end{array}$ & Nil & Nil & Nil \\
\hline \multirow[t]{3}{*}{ 13/At home. } & $\begin{array}{l}\text { (repeatedly play her own toes, liked to } \\
\text { sit on the ground and repeatedly moved } \\
\text { back and fro), picking something on the } \\
\text { ground into mouth. }\end{array}$ & & & \\
\hline & $\begin{array}{l}\text { 2. Unlike to actively communicate with } \\
\text { others and less spontaneous speech } \\
\text { with dysarthria sometimes. 3.Liked to } \\
\text { rummage through others' }\end{array}$ & & & \\
\hline & belongings. & & & \\
\hline G/10-04-2013 25-04-20 & During hospitalization: & NE at admission: & $\begin{array}{l}\text { 1 hour VEEG: Sleep- } \\
\text { activity left }\end{array}$ & 1. The long-term \\
\hline $13 /$ Hospitalization at & 1. After initial 3 day course MPN & Spontaneous & $\begin{array}{l}\text { side frontal-temporal } \\
\text { IEDs }\end{array}$ & $\begin{array}{l}\text { high-dose steroid } \\
\text { treatment regimen } \\
\text { given. }\end{array}$ \\
\hline \multirow[t]{9}{*}{ GZWCMC. } & given, eye-contact showed a little bit & language less & without clinical events. & \\
\hline & better. 2 . The frequencies of & with dysarthria; & & $\begin{array}{l}\text { 2. The dose of MPN } \\
\text { was gradually tapered } \\
\text { from } 10-5-2.5-1.25 \\
\mathrm{mg} / \mathrm{kg} / \mathrm{d} \text { at the } 3 \\
\text { days interval, and } \\
\text { changed into the oral } \\
\text { prednisone }(1.5 \mathrm{mg} / \\
\mathrm{kg} / \mathrm{d}) \text { at discharge. }\end{array}$ \\
\hline & eye-contact better and temper tantrum & unwilling to & & \\
\hline & less, after 8 day course MPN & answer. & & \\
\hline & treatment. 3. At discharge, she could & & & \\
\hline & even erect her thumb as a "praise & & & \\
\hline & symbol"; more vocalizations, although & & & \\
\hline & only with "Yo, Yo" sounds; more & & & \\
\hline & positive attitudes about circumstances. & & & \\
\hline \multirow[t]{2}{*}{ H/08-05-2013 14-05-20 } & 1. At home (25-04-2017 08-05-2017): & NE at admission: & $\begin{array}{l}\text { 1 hour VEEG: Sleep- } \\
\text { activity left }\end{array}$ & $\begin{array}{l}\text { 1. Repeated } 5 \sim \text { day } \\
\text { course of IVIG ( } 400 \\
\mathrm{mg} / \mathrm{kg} / \mathrm{d}) \text {. }\end{array}$ \\
\hline & & & & $\begin{array}{l}\text { 2. Oral prednisone } \\
(1.5 \mathrm{mg} / \mathrm{kg} / \mathrm{d}) \\
\text { continued. }\end{array}$ \\
\hline
\end{tabular}


Landau-Kleffner Syndrome: An Unusual Case With Progressive Ataxia Prior To Language Case Report Regression And Autistic-Like Behaviors

\begin{tabular}{|c|c|c|c|c|}
\hline 13/Hospitalization at & Behavior disturbances getting better, & Could actively & $\begin{array}{l}\text { side frontal IEDs } \\
\text { without clinical }\end{array}$ & \\
\hline \multirow[t]{10}{*}{ GZWCMC. } & e.g. controlling emotions better; no & laugh at doctor & events. & \\
\hline & longer taking others' things; could & with "Yo, Yo" & & \\
\hline & even happily say "grandmother" when & sounds, and even & & \\
\hline & returned home after discharge last & could response & & \\
\hline & time, although no more spontaneous & and give her toy & & \\
\hline & words thereafter; a couple of times, & to doctor when & & \\
\hline & could even eat rice by herself. 2 . & asked, although & & \\
\hline & During hospitalization: Behaviors & clapping her & & \\
\hline & getting more organized; more & $\begin{array}{l}\text { palms purposelessly } \\
\text { sometimes. }\end{array}$ & & \\
\hline & $\begin{array}{l}\text { utterance of "Yo, Yo" sounds; could } \\
\text { eat between-meal nibbles by herself, } \\
\text { although still need to be fed by mother } \\
\text { three meals a day; sometimes still liked to } \\
\text { clap her palms purposelessly. }\end{array}$ & & & \\
\hline I/29-05-2013 01-06-201 & 1. At home (14-05-2013 29-05-2013): & NE at admission: & $\begin{array}{l}\text { 1 hour VEEG: Sleep- } \\
\text { activity }\end{array}$ & $\begin{array}{l}\text { 1. Oral prednisone } \\
(1.0 \mathrm{mg} / \mathrm{kg} / \mathrm{d}) \\
\text { continued. }\end{array}$ \\
\hline 3/Hospitalization at & Better controlling her emotions; could & Could answer & $\begin{array}{l}\text { left side frontal IEDs } \\
\text { without }\end{array}$ & \\
\hline \multirow[t]{5}{*}{ GZWCMC. } & follow some instructions. 2. During & simple questions; & clinical events. & \\
\hline & hospitalization: Said simple words; & even could recite & & \\
\hline & $\begin{array}{l}\text { could understand instructions sometimes; } \\
\text { unwilling to answer }\end{array}$ & whole Chinese & & \\
\hline & sometimes. & poem "goose" & & \\
\hline & & when asked. & & \\
\hline \multirow[t]{2}{*}{ J/29-07-2013 01-08-20 } & 1. At home (01-06-2013 29-07-2013): & NE at admission: & 1 hour VEEG: Normal. & $\begin{array}{l}\text { 1. The diagnosis made. } \\
\text { Of confirmative LKS } \\
\text { was }\end{array}$ \\
\hline & & & & $\begin{array}{l}\text { 2. Oral prednisone } \\
(0.5 \mathrm{mg} / \mathrm{kg} / \mathrm{d}) \\
\text { continued. }\end{array}$ \\
\hline 13/Hospitalization at & Language ability and behavior & Could take and & & \\
\hline GZWCMC & disturbances markedly improved with & $\begin{array}{l}\text { show a toy to doctor and } \\
\text { say }\end{array}$ & & \\
\hline \multirow[t]{5}{*}{ (after 8 months of onset). } & almost returned to normal level; could & "garden baby"; & & \\
\hline & eat by self; played with other children; & Corporation during NE. & & \\
\hline & picked someone she liked. 2. During & & & \\
\hline & hospitalization: Spoke freely, and & & & \\
\hline & acted according to instructions. & & & \\
\hline \multirow[t]{3}{*}{$\begin{array}{l}\text { K/28-08-2013/Outpatien t } \\
\text { at GZWCMC. }\end{array}$} & At home (01-08-2013 28-08-2013): & $\begin{array}{l}\text { NE at outpatient: Saw doctor } \\
\text { with }\end{array}$ & Nil & $\begin{array}{l}\text { Oral prednisone } \\
(0.5 \mathrm{mg} / \mathrm{kg} / \mathrm{d}) \\
\text { continued. }\end{array}$ \\
\hline & & smile. & & \\
\hline & Uneventful with eager to go to school. & & & \\
\hline \multirow[t]{2}{*}{$\begin{array}{l}\text { L/25-09-2013/Outpatien t } \\
\text { at GZWCMC. }\end{array}$} & At home (28-08-2013 25-09-2013): & Saw doctor with & Nil & $\begin{array}{l}\text { Oral prednisone } \\
(0.25 \mathrm{mg} / \mathrm{kg} / \mathrm{d}) \\
\text { continued. }\end{array}$ \\
\hline & $\begin{array}{l}\text { Uneventful with eager to go to school; } \\
\text { liked to played with other children }\end{array}$ & smile; answered accordingly. & & \\
\hline \multirow[t]{2}{*}{ M/23-10-2013/Outpatie } & At home (25-09-2013 23-10-2013): & Happily laughed & 1 hour VEEG: Normal & $\begin{array}{l}\text { Oral prednisone } 0.125 \\
\mathrm{mg} / \mathrm{kg} / \mathrm{d}) \text { continued. }\end{array}$ \\
\hline & $\begin{array}{l}\text { Returned to normal child's situation with } \\
\text { eager to go to school, and loved to play } \\
\text { with other children. }\end{array}$ & & & \\
\hline \multirow[t]{3}{*}{ nt at GZWCMC. } & & when knew she & & \\
\hline & & could return to & & \\
\hline & & kindergarten. & & \\
\hline
\end{tabular}




\section{Case Report Dr. Wen-Xiong Chen}

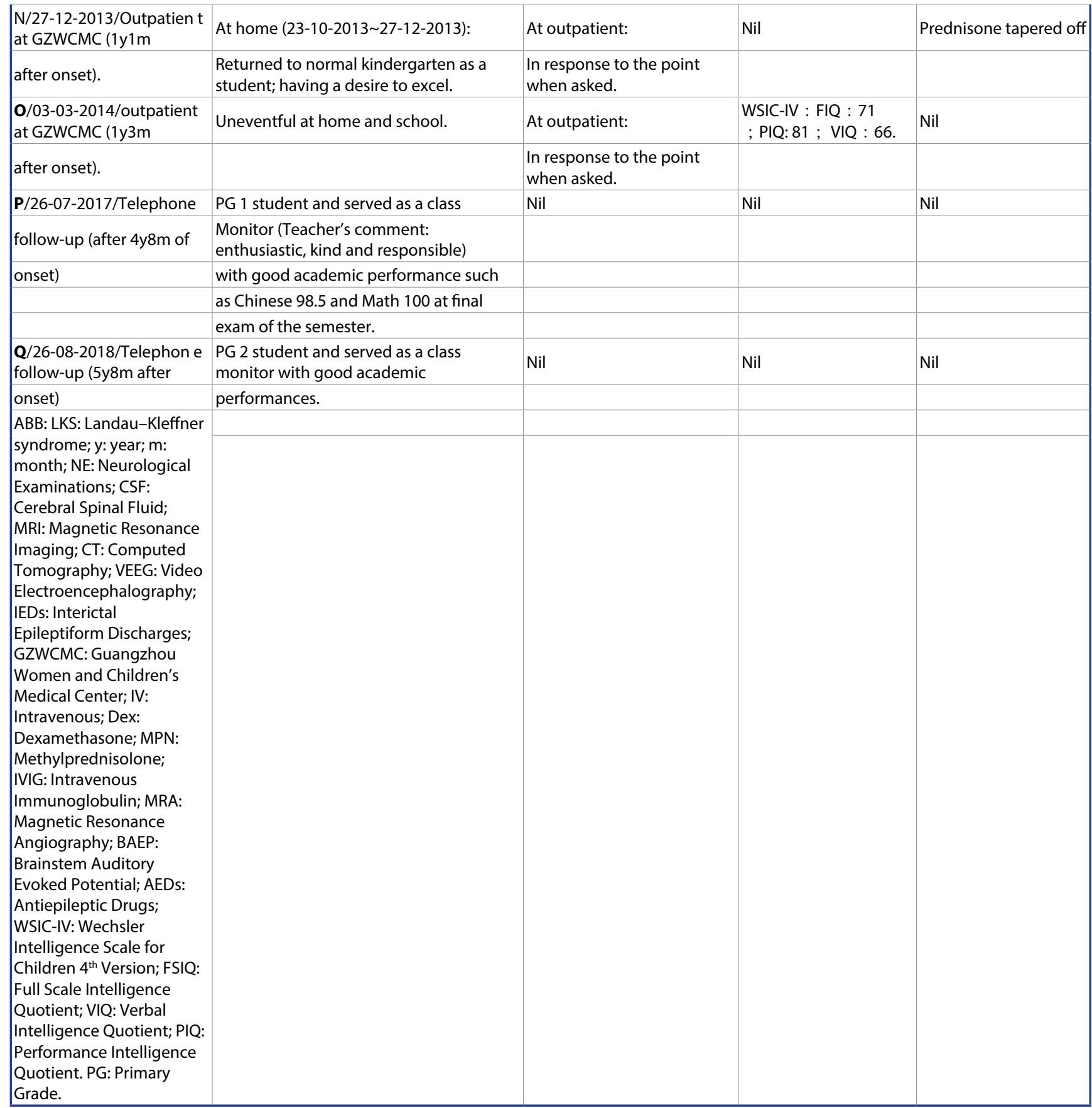

along with hemiparesis, urinary incontinence and convulsions at the age of 4 years and 10 months, followed by acquired aphasia a year later.

\section{- LKS and EEG findings/seizures}

Despite the severe electroencephalographic abnormalities, seizures never occur in the 20$30 \%$ of LKS patients [10]. The types of the seizures reported in the LKS can be different, including partial complex, partial clonic, generalized tonic-clonic, and atonic seizures
$[3,11]$, although absence of clinical seizures was found in our case through the course.

No single epileptiform abnormality could consist of all cases of LKS [12]. The electroencephalographic manifestations of the epileptiform disorder included generalized, bilateral, focal or multifocal, spike or spike-wave discharges $(1 \sim 3 \mathrm{~Hz})$, usually with a central or temporal lobe predominance [13]. The abnormalities were frequently activated by sleep, particularly at sleep onset [13] and during slow wave sleep. The pattern of continuous spikes and 
waves during slow sleep (CSWS) or electrical status epilepticus in sleep (ESES) in patients with LKS tends to be unilateral or clearly lateralized. The presence of CSWS/ESES in LKS appears to relate to the continuation of language impairments, and if lasting more than 3 years may be associated with the long-term language deficits [14].

The presence of CSWS/ESES is not a prerequisite for a diagnosis of LKS. In one case series of 25 LKS patients, the CSWS pattern was found in only 9 patients [15]. Another study [16] reported three children whose sleep EEG with normal outcomes after several months of the onset of language regression, although a final diagnosis of LKS was confirmed when subsequent sleep EEG showed interictal epileptiform discharges (IEDs). Similarly, our case did not demonstrate the CSWS/ESES, instead consistent with sleepactivated IEDs.

The symptoms of the case in our study were related to the severity of the epileptiform activity. For instance, the consistent changes of sleepactivated bilateral frontal, central and temporal IEDs $(1-3 \mathrm{~Hz})$ were found before steroid plus IVIG treatment (Table 1: A). Subsequently, the improvements of ataxia associated with the normal EEG after the $1^{\text {st }}$ steroid plus treatment (Table 1: B); the gradual ameliorations of autistic-like behaviors as well as language ability either on auditory or on expressive after the $2^{\text {nd }}$ long-term high dose steroid plus treatment, in accordance with the gradual improvements of serial EEG outcomes e.g. from bilateral IEDs (Table 1: E) to unilateral IEDs (Table 1: G, H, I), and final normal EEG (Table 1: J, M).

\section{- LKS and language regressions}

The language loss is characterized by a severe disturbance of auditory language comprehension and combined with a substantial disruption of expressive language [3]. Children may fail to orient to their name being called or comprehend orally presented information that they could previously attend to and understand without difficulty. Similarly, current case who did not understand what parents or grandmother's said, e.g. asking her to call grandmother, she went to get a broom instead (Table 1: D), although the outcomes of auditory exams and brainstem auditory evoked potentials were normal. Similarly, one study included 29 LKS patients reported all had moderate to severe auditory verbal agnosia [10].
Basically, the receptive language difficulties were accompanied or closely followed by reductions and distortions of verbal output. Speech became "garbled" and dysfluent, marked by articulatory errors, word-finding difficulties, and declines in the frequency, length, and complexity of verbal utterances [3]. Likewise, our case occurred both in the verbal auditory agnosia and expressive aphasia simultaneously, gradually developed just only with "Yo Yo" jargon, although being mutism at times (Table 1: D).

\section{- LKS and behavioral disturbances/ cognitive impairments}

About two thirds of children with LKS emerge behavioral disturbances. The most frequently observed behavioral problems are attentional deficits, impulsivity, distractibility, and hyperactivity; others consisted of aggression, anger with tantrums, withdrawal, social deficits, and sometimes autistic-like behaviors such as avoidance and withdrawal, resistance to change in daily activity, gestural stereotypes, echolalia and echopraxia, hyperlexia, or psychotic-like presentations $[3,17]$.

Nonlinguistic cognitive functions were affected in approximately half of the patients [18]. A subtle behavioral or cognitive manifestation of epilepsy can be defined as follows with the two ways [19]. First, epileptiform discharges not presenting as obvious seizures may nevertheless affect cognition and/or behavior. Second, the actual seizures may be obvious but the way they affect cognition or behavior may not be. These impairments may be global or focal, depending on the location of the epileptic discharges, and progressive, presumably related to increasing epileptiform activity. Studies demonstrated that interictal epileptiform activity could disrupt cognition. Similarly, our case existed cognitive dysfunction, such as memory decline and learning disorder, as well as behavioral disturbances such as autistic like behaviors (Table 1), which was related to sleep-activity IEDs of EEG. In LKS, the autistic features can be the results of the epilepsy itself [20].

A retrospective study of 14 LKS children [21] has revealed that the $57 \%$ cases evidenced attentional or other behavioral problems, 50 57\% having deficits in auditory working memory and verbal memory. Academically, the majority had poor reading fluency and comprehension, and 50\% exhibited difficulty with mathematics. The global intellectual functioning ranged from 59 to 101 . As a contrast, the full scale IQ of our 
case was 71 tested at the time after her returning to kindergarten, although the verbal IQ was still lower than that of performance IQ (Table 1: O).

\section{- LKS and etiology}

The etiology of LKS is still unknown [22], but involvement of the frontal and/or temporal lobes is frequently stated [23]. It is unclear whether LKS represents the late manifestation of preexisting anomalies in neurodevelopment or the result of acquired pathogenetic influences such as an abnormal autoimmune response or both. Like our case (Table 1), the most effective treatment has been used with long-term cortico-therapy in high doses, which supporting possibilities the presumption that the participation of autoimmune factors in the origin of LKS. Recently, the striking finding of mutations in the N-methyl-D-aspartate (NMDA) receptor subunit gene GRIN2A as the first monogenic cause in up to $20 \%$ of patients with epilepsyaphasia spectrum including LKS suggests that excitatory glutamate receptors play a key role in these disorders [24, 25], although our case didn't carry out genetic research.

MRI scans are normal in most LKS cases, but PET and SPECT studies have showed focal or multifocal changes or perfusion asymmetries predominantly affecting, but not restricted to the temporal regions [26]. Functional MRI study [27] suggested intact temporal lobe processing but an altered temporal to frontal connectivity.

\section{- LKS and diagnosis}

The symptoms of LKS are heterogeneous, and these symptoms can lead to misdiagnosis, which makes the EEG examination as an important determinant in the differential diagnosis. One national study found that the parents of children with LKS often struggled with the local health authorities to obtain the correct diagnosis and adequate help [6].

A delay between initial symptoms and definitive diagnosis is not unusual in rare diseases. Sometimes, rarely also the mild neurological symptomatology can be seen as accompanying signs of the disease. Likewise, our case not only developed atypical initial neurological symptoms of ataxia, but also did not experience epileptic seizures; secondly the EEG pattern did not demonstrate CSWS/ESES, instead with IEDs; thirdly, the initial symptoms of behavioral problems and language regression developed insidiously. For instance, the status of restlessness or agitation occurred only sometimes during hospitalization (Table 1: B) or somewhat less desire to communicate with others at outpatient clinic (Table 1: C) at that time when the symptom of ataxia was recovery; Furthermore, there were no family history of seizures of this case. Taken the above evidences together, causing the challenges to diagnose of LKS for the case. Specifically, initial diagnosis of progressive cerebellar ataxia (Table 1: A), ensued the suspected LKS (behavioral problems and language regressions and cognitive impairments, plus sleep-activated IEDs), followed confirmative LKS diagnosis (constellation of clinical findings plus the severity of symptoms in accordance with the changes of serial EEGs outcomes) (Table 1).

\section{- LKS and Treatment}

In view of the relationship between the occurrence of CSWS/ESES and the language deterioration, early and aggressive therapy is mandatory [10]. Early effective treatment may reverse some of these features [28]. Clinical practice suggests that amelioration in neuropsychological functioning may be related to control of ongoing epileptiform activity in LKS. Several antiepileptic drugs (AEDs), such as valproate, ethosuximide, clonazepam, or clobazam have been demonstrated to be effective.

However, standard antiepileptic drugs often control the clinical seizure activity but may not improve the neuropsychologic dysfunction in LKS. Steroids seem to have more longlasting effects. Early diagnosis, before mutism or global deterioration develops, appears to be esential for effective therapy with minimal neuropsychological sequelae [29]. The series including 44 patients treated with hydrocortisone starting at $5 \mathrm{mg} / \mathrm{kg} /$ day with a maintenance dose of $2 \mathrm{mg} / \mathrm{kg} /$ day until the end of a full year of treatment [30]. More than 75\% of the patients responded to this regimen within the first 3 months, with normalization of the EEG in about half of them. Although relapse occurred in 14 patients, 20 patients (45.4\%) were long-term responders. As a contrast, our steroids long-term high-dose regimen treated with methylprednisolone beginning at $10 \mathrm{mg} /$ $\mathrm{kg} /$ days with a maintenance dose of $1 \mathrm{mg} /$ $\mathrm{kg} /$ day of prednisone until the end of a 7.5 months of treatment plus the intermittent infusions of intravenous immunoglobulin (IVIG) (Table 1: $\mathbf{G} \sim \mathbf{M}$ ). In terms of novel treatments, adrenocorticotropic hormone is currently preferred due to its clinical and electroencephalographic efficacy. 
Amongst the other therapeutic approaches, the benefits of IVIG were not confirmed in a recent series [31], although the promising result in some cases has also been reported. Data on the use of vagus nerve stimulation and ketogenic diet were too scarce to draw conclusions [32, 33]. In addition, surgery using multiple subpial transections can be considered in the refractory cases, although negative outcomes were also argued [34].

\section{- LKS and prognosis}

The long-term outcome of LKS is not completely clear. The outcome of the disease is variable, and serious disturbances of language remain sometimes until adulthood [35]. In addition, the course of recovery in LKS is also comparatively slow or limited. Likewise, our case returned to normal school 1y1m after onset (Table 1: N).

Some studies indicated that whether the aphasia onset occurred before or after 5 years of age had an important impact on long-term outcome [36], but other studies did not confirm this prospective [7]. Our case had relatively good long-term outcomes, although whose onset age was before age 5 (Table 1: A). Nevertheless, long-term language and language-related difficulties may also occur with later onset [7]. One study [6] found that children who had experienced a short initial aphasic period and marked fluctuations in speech ability had the best prognosis with respect to future language outcome.

Patients with LKS had an overall poor quality of life [7], the prognosis of LKS is known to be difficult to predict and uncertain since speech deficiencies typically persist [36]. Fortunately, the long-term prognosis of the case in our study was good as she had a good academic performances, as well as served as monitor of the class 5y8m after the onset (Table 1: P \& Q), although she did not repeat IQ test.

\section{Conclusion}

LKS is heterogeneity entity, especially for those with the atypical onset such as ataxia, as well as absence of clinical seizures. The combination of long-term high-dose steroid plus IVIG regimens may be especially effective in LKS.

\section{Funding Source}

This research is supported by the grants of Science and Technology Department of Guangdong Province of China (2013B021800046 \& 2016A020215019) and Doctoral Fund of Guangzhou Women and Children's Medical Center (5001-2170057), and partly supported by the key projects fund of Ministry of science and technology of China (2016YFC1306200).

\section{Conflict of Interest}

There are no conflicts of interest for all authors in this study.

\section{Author Contributions}

CWX conceptualized and drafted the study. CWX, YSD, GYY, ZYN and ZKL clinically treated and long-term assessed the subject. NSY, ZYY, PBW and OSP performed serial neuroelectrophysiological assessments. All authors have agreed on the final version.

\section{References}

1. Landau WM, Kleffner FR. Syndrome of acquired aphasia with convulsive disorder in children. Neurology 7(8), 523-530 (1957).

2. Landau WM, Kleffner FR. The Landau-Kleffner syndrome. Epilepsia 50(S7), 3 (2009).

3. Stefanatos G. Changing perspectives on Landau-Kleffner syndrome. Clin. Neuropsychol 25(6), 963-988 (2011).

4. Berg AT, Berkovic SF, Brodie MJ, et al. Revised terminology and concepts for organization of seizures and epilepsies: report of the ILAE Commission on Classification and Terminology, 2005-2009. Epilepsia 51(4), 676-685 (2010).

5. Kaga M, Inagaki M, Ohta R. Epidemiological study of Landau-Kleffner syndrome (LKS).
Japan. Brain. Dev 36(4), 284-286 (2014).

6. Cockerell I, Bølling G, Nakken KO. Landau-Kleffner syndrome in Norway: longterm prognosis and experiences with the health services and educational systems. Epilepsy. Behav 21(2), 153-159 (2011).

7. Duran $M H$, Guimarães CA, Medeiros LL, et al. Landau-Kleffner syndrome: long-term follow-up. Brain. Dev 31(1), 58-63 (2009).

8. Humphrey IL 3rd, Knipstein R, Bumpass ER. Gradually developing aphasia in children. A diagnostic problem. J. Am. Acad. Child. Psychiatry 14(4), 652-665 (1975).

9. Nakano S, Okuno T, Mikawa H. Landau-Kleffner syndrome. EEG topographic studies. Brain. Dev 11(1), 43-50 (1989).

10. Caraballo RH, Cejas N, Chamorro N, et al.
Landau-Kleffner syndrome: a study of 29 patients.

11. Seizure 23(2), 98-104 (2014).

12. Deonna T, Roulet-Perez E. Early-onset acquired epileptic aphasia (Landau-Kleffner syndrome, LKS) and regressive autistic disorders with epileptic EEG abnormalities: the continuing debate. Brain. Dev 32(9), 746-752 (2010).

13. Prasad AN, Stafstrom CF, Holmes GL. Alternative epilepsy therapies: the ketogenic diet, immunoglobulins, and steroids. Epilepsia 37(S1), 81-95 (1996).

14. Rodriguez I, Niedermeyer E. The aphasia-epilepsy syndrome in children: electroencephalographic aspects. Clin. Electroencephalogr 13(1), 23-35 (1982). 


\section{Case Report Dr. Wen-Xiong Chen}

15. Robinson RO, Baird G, Robinson G, et al. Landau-Kleffner syndrome: course and correlates with outcome. Dev. Med. Child. Neurol 43(4), 243-247 (2001).

16. McVicar KA, Ballaban-Gil K, Rapin I, et al. Epileptiform EEG abnormalities in children with language regression. Neurology 65(1), 129-131(2005).

17. van Bogaert $P$, King MD, Paquier $P$, et al Acquired auditory agnosia in childhood and normal sleep electroencephalography subsequently diagnosed as Landau-Kleffner syndrome: a report of three cases. Dev. Med. Child. Neurol 55(6), 575-579 (2013).

18. Hirsch E, Valenti MP, Rudolf G, et al. Landau-Kleffner syndrome is not an eponymic badge of ignorance. Epilepsy. Res 1(S1), 239-247 (2006).

19. Deonna T, Beaumanoir A, Gaillard F, et al. Acquired aphasia in childhood with seizure disorder: a heterogeneous syndrome. Neuropadiatrie 8(3), 263-273 (1977).

20. Besag F, Gobbi G, Aldenkamp A, et al. Psychiatric and Behavioural Disorders in Children with Epilepsy (ILAE Task Force Report): Subtle behavioural and cognitive manifestations of epilepsy in children. Epileptic. Disord 18(S1), 49-54 (2016).

21. Besag F, Aldenkamp A, Caplan R, et al. Psychiatric and Behavioural Disorders in Children with Epilepsy: an ILAE Task Force Report. Epileptic. Disord I(S1), 1-86 (2016).

22. Riccio CA, Vidrine SM, Cohen MJ, et al. Neurocognitive and behavioral profiles of children with Landau-Kleffner syndrome. Appl. Neuropsychol. Child 6(4), 345-354 (2017).
23. Van Bogaert P, Paquier PF. Landau-Kleffner syndrome: 50 years after. Epilepsia 50(S7), 1-2 (2009).

24. Nieuwenhuis L, Nicolai J. The pathophysiological mechanisms of cognitive and behavioral disturbances in children with Landau-Kleffner syndrome or epilepsy with continuous spike-and-waves during slowwave sleep. Seizure 15(4), 249-258 (2006).

25. Conroy J, McGettigan PA, McCreary D, et al. Towards the identification of a genetic basis for Landau-Kleffner syndrome. Epilepsia 55(6), 858-865 (2014).

26. Turner SJ, Morgan AT, Perez ER, et al. New genes for focal epilepsies with speech and language disorders. Curr. Neurol. Neurosci. Rep 15(6), 35 (2015).

27. Nemati R, Nabipour I, Javadi $\mathrm{H}$, et al. Regional Cerebral Blood-Flow with 99mTcECD Brain Perfusion SPECT in Landau-Kleffner Syndrome: Report of Two Cases. Case. Rep. Radiol 2014(617343), 1-5 (2014).

28. Pullens P, Pullens W, Blau V, et al. Evidence for normal letter-sound integration, but altered language pathways in a case of recovered Landau-Kleffner Syndrome. Brain. Cogn 99(1), 32-45 (2015).

29. Besag F, Gobbi G, Aldenkamp A, et al. Psychiatric and Behavioural Disorders in Children with Epilepsy (ILAE Task Force Report): Behavioural and psychiatric disorders associated with childhood epilepsy syndromes. Epileptic. Disord 18(S1), 37-48 (2016).

30. Marescaux C, Hirsch E, Finck S, et al. Landau-Kleffner Syndrome: a pharmacologic study of
31. five cases. Epilepsia 31(6), 768-777 (1990).

32. Buzatu M, Bulteau C, Altuzarra C, et al. Corticosteroids as treatment of epileptic syndromes with continuous spike-waves during slow-wave sleep. Epilepsia 50 (S7), 68-72 (2009)

33. Arts WF, Aarsen FK, Scheltens-de Boer M et al. Landau-Kleffner syndrome and CSWS syndrome: treatment with intravenous immunoglobulins. Epilepsia 50 (S7), 55-58 (2009).

34. Lagae L. Rational treatment options with AEDs and ketogenic diet in Landau-Kleffner syndrome: still waiting after all these years. Epilepsia 50 (S7), 59-62 (2009).

35. Van Bogaert $P$, Aeby A, De Borchgrave V, et al. The epileptic syndromes with continuous spikes and waves during slow sleep: definition and management guidelines. Acta. Neurol. Belg 106(2), 52-60 (2006).

36. Downes M, Greenaway $R$, Clark M, et al. Outcome following multiple subpial transection in Landau-Kleffner syndrome and related regression. Epilepsia 56(11), 1760-1766 (2015).

37. Smith MC, Hoeppner TJ. Epileptic encephalopathy of late childhood: Landau-Kleffner syndrome and the syndrome of continuous spikes and waves during slow-wave sleep. J. Clin. Neurophysiol 20(6), 462-472 (2003).

38. Bishop DV. Age of onset and outcome in 'acquired aphasia with convulsive disorder' (Landau-Kleffner syndrome). Dev. Med. Child. Neurol 27(6), 705-712 (1985). 